\title{
Short Circuit: A Failing Technology for Administering Justice in Nunavut
}

\section{David Matyas*}

If all you have is a hammer everything looks like a nail, but if all you have is a circuit court what happens to the administration of justice? This paper explores the history and contemporary usages of the itinerant 'circuit court' in the Canadian Arctic. Presenting the circuit court as a technology of justice, the paper explores why and how this instrument has been employed and the possibilities it constrains. Looking to the challenges of administering justice in contemporary Nunavut, the paper argues that a different type of technology may be needed: One that facilitates work, rather than exercises control; allows for specialized outcomes in place of compliant results; and that focusses on the growth of justice instead of products that are just. The paper concludes by exploring the local, sedentary, judge-based system of Greenland-steeped in its civilian procedural law-as a compelling alternative technology to the circuit court in Nunavut.

Pour qui n'a qu'un marteau, tout ressemble à un clou. Cependant, lorsque le seul tribunal accessible est un tribunal itinérant, qu'advient-il de l'administration de la justice? Dans ce texte, l'auteur explore l'utilisation passée et actuelle du tribunal itinérant dans l'Arctique canadien. Après avoir décrit le système de tribunaux itinérants comme une technologie de justice, l'auteur explique comment et pourquoi ce système a été utilisé et l'est encore et examine les contraintes qu'il comporte. Dans le contexte des défis que pose l'administration de la justice au Nunavut contemporain, l'auteur affirme qu'un type différent de technologie est nécessaire. Il est souhaitable de s'orienter vers un système qui permet de faciliter la tâche plutôt que d'exercer un contrôle, qui mène à des résultats spécialisés plutôt qu'à des résultats conformes et qui met l'accent sur l'évolution de la justice plutôt que sur l'obtention de produits qui sont justes. Dans la dernière partie de son texte, l'auteur explore le système de tribunaux sédentaires du Groenland, composé de juges locaux et enraciné dans ses règles de droit procédural civil, qui représente la solution de rechange à adopter pour remplacer le tribunal itinérant du Nunavut.

\footnotetext{
* David Matyas MPhil (Oxford) is a recent graduate of the McGill University BCL/LLB program and former international development practitioner. In 2019, he will be completing a judicial clerkship at the Supreme Court of Canada. The topic for this paper was inspired by the author's work experience at Maliiganik Tukisiiniakvik, one of Nunavut's legal aid clinics in the Qikiqtaaluk region, during the summer of 2017 and generously supported by the McGill International Human Rights Internship Program and Robert S. Litvack Award Fund. The author would like to thank Professor Nandini Ramanujam for her tireless support, feedback, and encouragement with this research as well as Professor George Wenzel for his insights and instructive seminar. The views expressed here are the authors alone and do not purport to reflect the views of any of the above institutions or organizations.
} 


\section{INTRODUCTION}

The Arctic is a land rich with Indigenous technology. From the sloping dome of the igloo to the caribou herding inukshuk, the Inuit have, over generations, developed a diversity of tools to allow them to thrive in the North. These context-specific technologies have been designed to help their users reach certain goals and their use, in turn, shapes how those goals are achieved. Against the dark and cold of winter, the kudlik - a seal-oil lamp with willow wick - provides light and warmth. Across a vast geography, the qamutik - the famous sled bound with knots rather than nails-facilitates travel across the ice. But a Kudlik is not an oven and a qamutik is not a wheel-barrow. Just try baking a pizza on the former or travelling a gravel track with the latter.

Like these Arctic technologies - which address certain goals and have, through their use, shaped ways in which they can be realized - technologies of justice are both developed to confront needs and have, in turn, altered comprehensions of those objectives. This paper explores a particular technology for the provision of justice that has become ubiquitous in the Canadian Arctic: the circuit court. Across the territory of Nunavut, parties consisting of judges, lawyers, translators and clerks board planes and travel thousands of kilometers to "sit court" in school gymnasiums and hotel meeting rooms. Circuit courts are, basically, "the practice of having judges of Superior Courts travel around the country from one venue to another to hear cases away from the permanent (principal) seat of the court." But when the "fly-in" or circuit court was initially designed what were its goals, and how does its structure shape how these goals are achieved? Do the goals of this imported technology align with traditional goals of Inuit justice? Looking forward, can this technology be repurposed to suit the contemporary needs of Nunavummiut or are different technologies needed?

Section II of this paper presents the concept of "technology" as "practice' or a 'way of doing something,' and illustrates how this notion can help think about the circuit court. Section III traces the history of circuit courts in England, the Cape Colony of present day South Africa, and North America. These short vignettes focus on the goals for which this technology was developed and how the technology was, over time, repurposed to achieve alternative objectives. Section IV provides a description of the contemporary circuit court in Nunavut and some common complaints lodged against it. In Section V, Inuit conceptions of justice are presented as a foil to the technology of the circuit court, problematizing the goals it seeks to pursue and the means through which these outcomes are achieved. Finally, Section VI discusses whether the circuit court technology can be repurposed to contemporary needs or if an alternative technology is needed. Is the circuit court a vehicle with wheels trying to travel a terrain that would do better with runners - a cart that should be a qamutik?

Much of the existing academic literature on circuit courts, such that it is, focusses on the historical experiences of judges and lawyers. It tends to chronicle the challenges they faced and how they lived their lives while travelling with the court. ${ }^{2}$ This paper works to move the discourse on circuit courts from this

1 HJ (Hennie) Erasmus, "Circuit Courts in the Cape Colony During the Nineteenth Century: Hazards \& Achievements" (2013) 19 Hazards and Achievements 266 at 267.

2 See for instance Erasmus, supra note 1; Maurice Healy, The Old Munster Circuit: A Book of Memories and Traditions (London, UK: Michael Joseph, 1939); Guy Fraker, "The Real Lincoln Highway: The Forgotten Lincoln Markers" (2004)

25:1 J Abraham Lincoln Assoc 76 at 78; Graham Price, "Lawyers and Judges on Circuit in Canada's Northwest

Territories in the Twentieth Century" (2014) 52 Alta L Rev 83. 
niche domain and instead situate it within the broader areas of judicial institutions, access to justice, and indigenous legal studies.

\section{THE CIRCUIT COURT AS TECHNOLOGY}

In a world of high speed communication, handheld electronics and complex industrial processes, there is a tendency to think of technology as a physical gadget or an electronic machine. But beyond the whirring of engines and blinking of lights, there are of diversity of technologies in existence in the world of sorts that would never make the cover of Wired magazine.

At its base, a technology can be understood as a "practice" 3 or a "way of doing something." As Boulding suggests, "there is a technology of prayer as well as of ploughing." While in languages such as French, "la technologie" has a meaning distinct from "la technique," in English these two words are conflated into a single word technology. ${ }^{6}$ The English technology encompasses both the "work of engineers," but also what Ellul describes as "a far wider concept, referring to efficient methods applicable in all areas (monetary, economic, athletic, etc.)." methods of meeting demands is an element that is often obfuscated in English discussions. A broad understanding of technology, accordingly, refers not only to spinning gears and flashing screens, but also "organization, procedures, symbols, new words, equations, and, most of all, a mindset." 8

Applications of technologies can help solve problems, but technologies can also shape the ways that problem-solvers relate to a problem at hand. Faced with a particular problem, a technology can provide a route to a particular solution. Outcomes are thus technology-specific. Moreover, their use can shape the ways that both the problem solvers and those experiencing the problem see the world around them. As the proverb goes, "if all you have is a hammer, everything looks like a nail."

Observing the education sector, for instance, there is a distinction to be made between the outcomebe it acquiring knowledge, learning to think critically, or signalling base proficiencies - and the technology used to reach those outcomes. In this schema, a school or university is a particular technology that will lead to a different sort of product ${ }^{9}$ than a critical pedagogical technology. ${ }^{10}$ But what types of technologies lead to which types of outcomes?

In her 1989 Massey Lectures, Ursula M Franklin provides distinctions between several types of technologies. These include "work-related" and "control related" technologies, "holistic" and "prescriptive" technologies, and "growth models" and "production models." Applying these distinctions

Ursula M Franklin, The Real World of Technology (Toronto: House of Anansi Press, 1990) at 2.

4 Kenneth E Boulding, "Technology and the Changing Social Order" in David Popenoe (ed) The Urban-Industrial

Frontier (New Brunswick: Rutgers University Press, 1969) cited in ibid at 6.

Ibid.

6 Jacques Ellul, Perspectives on our Age (Toronto: House of Anansi Press, 1997) at 26-27.

$7 \quad$ Ibid at 27.

$8 \quad$ Franklin, supra note 3 at 3.

$9 \quad$ Ibid at 22-23.

10 See for instance Paulo Freire, Pedagogy of the Oppressed (New York: Penguin Books, 1993); Shin Imai, "A CounterPedagogy for Social-Justice: Core Skills for Community Lawyering” (2002) 9:1 Clinical L Rev 195. 
to the field of justice can help classify the circuit court technology and analyze the range of outcomes that it may engender.

A first distinction Franklin makes is between "work-related technologies" and "control-related technologies." ${ }^{\prime 1}$ While the former are facilitators of practice-a potter's wheel easing the contours of ceramics - the latter enable increased control over a process, object or person - the technology of surnames as a means for a state to exercise control over large numbers of people not personally known by state administrators. ${ }^{12}$ Applying this distinction to the context of the northern circuit court, we can ask whether the circuit court was initially brought to the north to facilitate justice for Inuit-as a work-related technology—or as a mechanism of establishing and maintaining control over the administration of justice in this context.

A second distinction that Franklin draws is between "holistic technologies" and "prescriptive technologies." 13 With holistic technologies, control remains in the hands of a craftsperson - a calligrapher controls from start to finish the writing of a specialized greeting card. With prescriptive technologies, by contrast, it is the process that is specialized while the product itself is defined by its compliance-a greeting card company's specialized production allows for compliant holiday cards. Again, looking north, is the circuit court meant to produce specialized justice, tailored to the unique circumstances of a given case, or is it designed to create compliant and standardized justice across a vast geography?

Finally, Franklin distinguishes "growth models" from "production models." 14 A growth model of technology is one that cannot be "commandeered; it can only be nurtured and encouraged by providing a suitable environment [...] Growth occurs; it is not made." ${ }^{15}$ Contrarily, a production model is about controlling conditions to have certainty in the product created. Under the former technology, a carrot is grown - perhaps ending up a bit knobbly. Under the latter, a carrot is produced - where controlled conditions result in a perfect, consistent, predictable tuber. Looking at the circuit court, is it a model that allows justice to grow, nurturing conditions so that justice flourishes differently in different places? Or, on each and every iteration of the circuit court, are conditions controlled for certainty in the justice produced?

Ultimately, technologies classified along Franklin's various distinctions serve different purposes and have varied trade-offs. Related to holistic and prescriptive technologies, she notes that tasks which "require caring, whether for people or nature, any tasks that require immediate feedback and adjustment, are best done holistically [but, s] uch tasks cannot be planned, coordinated, and controlled the way prescriptive tasks must be." ${ }^{" 16}$ Related to growth and production models, she observes that while there is a predictability to production models, growth models exist in the more uncomfortable space of being unpredictable. ${ }^{17}$ Moreover, while growth models consider the environment and the surrounding context,

11 Franklin, supra note 3 at 10-11.

12 James C Scott, Seeing Like a State: How Certain Schemes to Improve the Human Condition Have Failed (New Haven: Yale University Press, 1998) at 67.

13 Franklin, supra note 3 at 10-12.

14 Ibid at 20.

15 Ibid.

$16 \quad$ Ibid at 17.

17 Ibid at 21. 
production models discount these elements, considering them as 'externalities' that are beyond their purview. ${ }^{18}$

So, what kind of "practice" is the circuit court technology and who controls it? The following section delves into the history of the circuit court in different contexts. Exploring the motivations for the circuit court's emergence and the outcomes it sought to realize, Section III provides short vignettes that help to classify the technology of the circuit court as a control-related, prescriptive technology, set within a production model.

\section{TRACING THE "PRACTICE” OF THE CIRCUIT COURT OVER TIME}

The history of using circuit courts in the administration of justice is a long one, spanning centuries and reaching over vast geographies. From Medieval England to $18^{\text {th }}$ century Canada, the American west, to the Cape Colony of what is now South Africa, circuit courts have been an important technology for the provision of justice to populations spread across large territories. Looking across these different contexts, one can discern common motivations and goals woven across the creation, adoption, or development of this technology. We begin this exploration in Medieval England before turning to the Cape Colony, Illinois, Upper Canada, and the Canadian Arctic.

\section{A. England and the Justices in Eyre}

Even prior to the Norman conquest, Kings in what is now England would send officials into the country to "hold the royal court." 19 At times the purview of these officials was general while at other times they were sent into the country to take special actions. From the perspective of administering justice, these courts served multiple purposes ranging from preserving public order to spreading legal norms. Over time, though the form of the technology itself barely changed, other purposes were layered upon these initial motivations including efficiency, effectiveness, and impartiality.

The itinerant courts in England gained traction and formality during the period between the twelfth and fourteenth centuries. In a system advanced by Henry II, groups of officials known at first as wandering justices, and eventually as justices in eyre ${ }^{20}$ travelled the country and ruled on broad civil, criminal, and administrative matters. ${ }^{21}$

This itinerant administration of justice consisted of a resource-intensive and broadly mandated "general eyre" as well as more specialised travelling courts. In the general eyre, a considerable portion of the King's government would travel to a county or shire to rule on a diversity of legal issues. A resource intensive process, the general eyre did not manage to visit particular communities frequently and thus its capacity to administer royal justice consistently was limited. ${ }^{22}$ To supplement this general eyre, the King sent travelling justices to rule on special assizes and writs. These special hearings were so significant to the administration of justice that even the Magna Carta references their role, noting at Clause 18; the King is

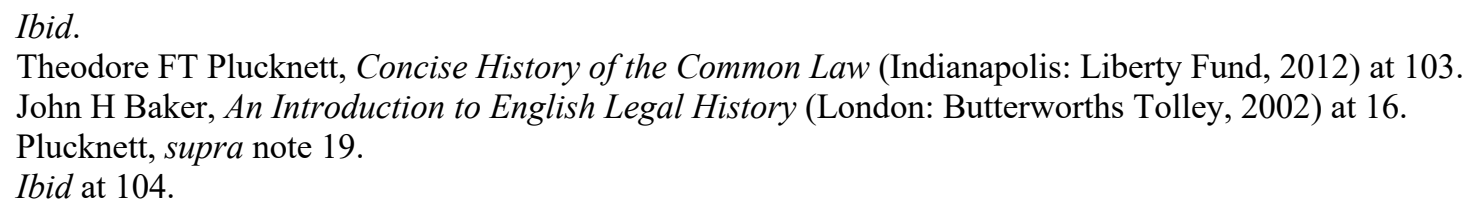


"to send two justices through every county four times in the year, who with four knights of each county chosen by that county court, are to hear those assizes in the county court." ${ }^{23}$

A major purpose of the circuit courts in medieval England was to spread justice and preserve public order. ${ }^{24}$ Following nearly twenty years of civil war known as "the Anarchy," Henry II hoped to bring stability to his dominion. ${ }^{25}$ The itinerant courts were a useful tool in this pursuit, allowing the King to project his power and signal his authority "over all sorts and conditions of men, from the baronial owners of great franchises and the sheriffs down to the meanest villain." 26 Through the justices and general eyre, the King could supervise local government and insulate his central authority from agglomerations of local power. ${ }^{27}$ This motivation suggests that the circuit court in the time of Henry II was used as a "controlrelated" technology rather than a "work-related technology."

Another major purpose was normative in nature. Through the itinerant courts, it became possible to spread across the vast country the "custom and practice of the King's Court." 28 The justices appointed by the King not only ruled on more established civil and criminal matters, they also played a role in enforcing the King's new legislation. ${ }^{29}$ By 1176 , the formality of this institution had grown and six circuits were established to fill this purpose. ${ }^{30}$ Effectively, by way of these travelling courts, both local populations and institutions became more accustomed to the King's legislative intent. Here, we see the circuit court being employed in a "prescriptive" manner, seeking to standardize compliance rather than foster justice specialized to the context through "holistic" means.

It is important at this point to acknowledge that throughout this early history, an alternative technology existed alongside the circuit court: the justice of the peace [J.P.]. Pre-dating the Norman conquest but gaining significance in the Tudor period, the J.P. was a prominent citizen in a locality tasked with keeping the peace. ${ }^{31}$ While the J.P. was instructed to "reserve more difficult cases for the King's circuit court," 32 it had decision-making power with major implications for the local populace. A key feature of its position was that it was "known to those who came before him or her" [emphasis added] ${ }^{33}$ and, similarly, that the J.P. in turn knew the persons who were appearing before it. Having a locally embedded, partial individual working alongside the circuit courts reflects an entirely different form of technology from the circuit courts. It is "work-related" where the circuit court is "control-related" and it is "holistic" where the circuit court is "prescriptive." Moreover, being locally embedded in a particular context, there is scope through this technology for justice to 'grow' rather than be 'produced.' The J.P. technology echoes throughout the

23 Magna Carta, 1215 Clause 18 cited in Ralph V Turner, Magna Carta Through the Ages (New York: Routledge, 2014) at 229.

24 Baker, supra note 20 at 14.

25 Ibid.

26 Plucknett, supra note 19.

27 Baker, supra note 20 at 16, 25.

28 Plucknett, supra note 19 at 144-145.

29 Baker, supra note 20 at 16.

30 Ibid.

31 Katherine Beaty Chiste, "The Justice of the Peace in History: Community and Restorative Justice" (2005) 68 Sask L Rev 153 at $154-155$.

32 Frederic W Maitland The Constitutional History of England: A Course of Lectures Delivered by F.W. Maitland (Cambridge: Cambridge University Press, 1911) at 208 cited in ibid at 155.

33 Chiste, supra note 31 at 169. 
history of the courts and seems to respond to some lacunae left by the circuit court. As will be shown below, the gap-filling role of the J.P. indeed continues in contemporary Nunavut.

As the circuit system became more entrenched, the motivations of projecting power and authority became secondary to concerns about delays (efficiency), the quality of judgements (effectiveness), and allowing for an open court. The circuits became more routine - establishing seasonal cycles - and more specialized - with jurisdiction limited to particular commissions. ${ }^{34}$ In remote areas with strong (or biased) local authorities, circuit courts could provide an impartiality in settling disputes that was otherwise not possible. This system endured in some form from the fourteenth century until 1971 when it was abolished. Even after it was abolished, the practice of central court judges in England travelling to rule on important cases continued. ${ }^{35}$ Importantly, though the circuit court's goals transformed over time in response to societal changes and developments in the legal system, the technology itself only changed in incremental ways.

\section{B. Itinerant Courts in the Cape Colony, Upper Canada, and Illinois}

The history of the travelling circuit courts in England highlights dual-purposes of projecting authority and administering justice in areas geographically removed from the Crown's centre of power. A similar set of concerns and priorities would accompany the administration of justice in the British colonies and early United States. In these places, circuit courts helped address the challenge of having populations who were both distant from the seat of centralized authority and isolated from Supreme or High Courts. ${ }^{36}$

The Cape Colony was a British colony within the borders of what is now South Africa. Formerly a Dutch colony and populated by Khoekhoe-, Xhosa-, English-, and Dutch-speaking individuals, it covered a large geography involving much of present-day South Africa. To help administer justice in this territory, the circuit court was first proposed around 1800 and formally established in 1811. In Ontario (then Upper Canada), the circuit court was a mainstay of the criminal justice system for over 200 years. ${ }^{37}$ In the US, the "circuit riding" endured for over 100 years, having been established in 1789 and continuing until 1891. ${ }^{38}$ In these contexts, like England, the motivations of using the circuit court for the control and standardization of justice are discernable. The use of circuit courts in these contexts also speaks to the logistical complexities of bringing court processes to remote communities.

As in England, the Cape Colony circuit courts allowed for the projection of judicial control and the standardization of justice. This projection of power, however, was accomplished on slightly different terms than in England. Firstly, in the Cape Colony, the circuit court was mandated with collecting information about the goings-on in the territory, ${ }^{39}$ allowing them to play a role in 'seeing' ${ }^{40}$ and thus managing the dispersed and diverse population. Secondly, providing accessible, standardized, 'prescriptive' justice was not about displacing a diversity of Indigenous justices - as in England — but

34 Baker, supra note 20 at 21.

35 Ibid at 21-22.

36 Erasmus, supra note 1 at 267.

37 Law Society of Upper Canada, Superior Court on Autumn Circuit, online: $<$ https://lso.ca/getdoc/fb7b6f10-83d2-4ea0b4b3-ec12e5f1f9e9/superior-court-on-autumn-circuit $\geq$.

38 Erasmus supra note 1 at 267.

39 Ibid at 270.

$40 \quad$ Scott, supra note 12. 
brokering norms between competing regimes. Amidst tensions between Dutch and English settlers, the circuit court could signal the integrity of the courts to all the territory's populations. To help facilitate this, the courts utilized translation and interpreters to ensure that the circuit court actually facilitated access. ${ }^{41}$ The Cape Colony judiciary was tinkering with the circuit court technology to suit the context.

Another way that the Cape Colony was incrementally changing the circuit court technology was in how the Cape Colony circuit court took the colonial environment into account. Racial tensions between the Khoikhoi and Xhosa populations, and white settlers were a major challenge for the administration of justice. Juries were predominantly white, and racial prejudices were often implicated in decisions. ${ }^{42}$ In some cases, despite considerable evidence, white jurists refused to convict white individuals alleged to have killed black individuals. ${ }^{43}$ Rather than succumbing to this prejudice, however, judges often tried to block juries from discriminatory verdicts, adhering to a principle that "justice shall be done against those guilty of any cruelty to the black man." 44 Here, a control-related and prescriptive technology was being used as a tool for normalizing access to justice and confronting prejudice. While perhaps patronizing, and certainly focused on control, this example suggests that the circuit courts may not have been, on the whole, an intentional tool of colonial oppression.

Upper Canada and Illinois provide examples of the logistical complexity of the circuit court in these vast geographies. In Upper Canada, the court would travel on four seasonal circuits, ruling on civil and criminal law files. ${ }^{45}$ Travel was slow and potentially dangerous, with one circuit's journey resulting in the deaths of a judge, solicitor general, treasurer of the law society, accused, and witnesses when the ship that they were travelling on sank while sailing to the Newcastle district. ${ }^{46}$ Circuit courts in these jurisdictions were also expensive, 'taxing the town's resources' and places of accommodation. ${ }^{47}$ In the Illinois Eighth Judicial Circuit, which Abraham Lincoln would famously ride as a lawyer, the court party travelled over four hundred miles in eleven weeks, twice annually. ${ }^{48}$

While the motivation for the circuit courts in these contexts - as in England - was gradually shifting towards goals such as efficiency, effectiveness, impartiality, and accessibility, the technology itself was not changing in substantial ways. Just as a qamatik would face challenges if pulled across a gravel track, so too this justice-standardizing and control-seeking court technology had begun to face challenges in trying to achieve efficiency and accessibility while maintaining the centuries old modality of the traveling band of justices and their entourage. Turning to the history of circuit courts in the Arctic reveals similar motivations and challenges.

\section{The History of Travelling Courts in the Arctic}

One of the first migratory court visits to the Arctic occurred in 1923 on Baffin Island and was a 'sailin' rather than 'fly-in' court. Chronicled by Grant in her text Arctic Justice: On Trial for Murder, Pond

\footnotetext{
41 Erasmus, supra note 1 at 287.

$42 \quad$ Ibid at 288.

43 Ibid at 289.

44 Ibid at 291.

45 Law Society of Upper Canada, supra note 37.

46 Ibid.

47 Ibid.

48 Fraker, supra note 2 at 78.
} 
Inlet, 1923, this case tried three Inuit-Aatitaaq, Naqallaq and Ululijarnaat-in the murder of Robert Janes, a Newfoundland sailor. ${ }^{49}$ Travelling on the CGS Arctic, a judge, a prosecution lawyer, a defense lawyer, and a Royal Canadian Mounted Police (RCMP) team sailed north under the instructions of the Mackenzie King Government.

Under the Inuit system of justice, Janes' killing had been a 'communal execution' taken under the guise of protecting the community from a reckless individual. ${ }^{50}$ For the Mackenzie King Government, however, it was a perfect opportunity to hold a show trial. This show trial was aimed, firstly, at demonstrating Canada's sovereign Arctic claim to foreign governments and, secondly, "to show the Inuit the firmness and fairness of Canadian justice." ${ }^{51}$ Projecting power and standardizing justice were thus prime motivations for the use of this technology, harkening back to the $13^{\text {th }}$ century English circuit courts.

At an earlier murder trial in 1917, the senior Crown prosecutor stated in his opening remarks:

These remote savages, really cannibals, the Eskimo [sic] of the Arctic regions have got to be taught to recognize the authority of the British Crown, and that the authority of the Crown and the Dominion of Canada, of which these countries are a part, extends to the furthermost limits of the frozen North [...] The great importance of this trial lies in this: that for the first time in history these people, these Arctic people, pre-historic people, people who are as nearly as possibly living to-day in the Stone Age, will be brought in contact with and will be taught what is the white-man's justice. ${ }^{52}$

Extending and standardizing the dominion of Canadian law was thus a common theme for courts travelling to the Arctic at this time.

This motivation, however, faced numerous challenges in the Arctic. In nearby Nunavik (Arctic Quebec), the expressed motivation of the circuit courts was a desire for an expansion of southern Canadian law into the Arctic. It has been argued, however, that this official policy was simply a smokescreen to protect the interests of white men operating in those areas. ${ }^{53}$ This settler-protecting motivation represents a significant variation from the use of the circuit court in places such as the Cape Colony where, it will be recalled, the courts attempted to play a role in normalizing laws, and thereby protecting Indigenous peoples from the transgressions of settlers. In the Arctic context, the 'prescriptive' technology was not creating standardized compliance related to justice. Facing not only a foreign system of justice but one

49 Shelagh D Grant, Arctic Justice: On Trial for Murder, Pond Inlet, 1923 (Montreal: McGill-Queen's University Press, 2014).

50 Peter Russell, “Arctic Justice: On Trial for Murder, Pond Inlet, 1923 by Shelagh D. Grant (review)” (2003) 73:1 U Toronto Q 287 at 288.

$51 \quad$ Ibid.

52 Natalia Loukacheva, The Arctic Promise: Legal and Political Autonomy of Greenland and Nunavut (Toronto: University of Toronto Press, 2007) at 88.

53 Ken Harper, Arctic Crime and Punishment (Toronto: Inhabit Media, 2015) at 76-78. 
that additionally did not treat Inuit equitably, the Nunavik circuit courts were plagued by challenges of local legitimacy. ${ }^{54}$

Alongside the circuit courts, the parallel J.P. technology was also being deployed. But, here too, the technology was being used in markedly different ways than in the south. Unlike in Upper Canada-where the J.P. was a prominent, respected local individual ${ }^{55}$-in the Arctic, the role was filled largely by commissioners and superintendents of the then North-West Mounted Police. ${ }^{56}$ Instead of putting locallyrespected individuals in this role, the individuals making decisions regarding justice were the same as those making the arrests. Collectively, the circuit court and justice of the peace technologies were leading to a considerable displacement of traditional Inuit instruments of law and conflict management. ${ }^{57}$ This foments an understanding that justice was being 'produced' upon the Inuit rather than 'grown' by or for them.

Eventually, as in the other contexts described above, the sovereignty-asserting and law-normalizing purposes of the circuit court started to shift towards a purpose of facilitating access to justice. In the $1950 \mathrm{~s}$, Justice Jack H Sissons was the first superior court justice appointed in the Northwest Territories and he endeavored to take justice to 'every man's door.' 58 This major shift in purpose was accompanied by some small adjustments in the technology itself. Initial efforts were made to integrate Inuit conceptions of justice into the Canadian system, including translating Canadian substantive and procedural concepts into an Inuit vernacular of justice, and also recognizing that, for some concepts, translation was not possible. ${ }^{59}$

Shifting our attention to the contemporary period, as the circuit court technology developed in the Arctic, have the purposes it serves and the goals it seeks to achieve changed again? Section IV provides an overview of the structure and function of Nunavut's modern-day circuit court and delves into the some of the challenges arising from this technology.

\section{STRUCTURE, FUNCTION, AND COMPLAINTS AGAINST NUNAVUT'S CIRCUIT COURT}

As of 2017, the population of Nunavut was $37,996,{ }^{60} 84 \%$ of whom are Inuit. ${ }^{61}$ This population is spread across 25 communities in an area of 1.9 million $\mathrm{km}^{2}$ - land that represents $20 \%$ of the Canadian land mass. ${ }^{62}$ Many of these communities are considerable distances from their regional hubs, be they Iqaluit in the Qikiqtaaluk region, Rankin Inlet in Kivalliq, or Cambridge Bay in Kitikmeot. None of the

54 Susan Drummond Incorporating the Familiar: An Investigation into Legal Sensibilities in Nunavik (Montreal: McGillQueen's University Press, 1997) at 51 cited in Justice J.E. Richard, "Susan Drummond, Incorporating the Familiar" (2001) 11:99 Windsor Rev Legal and Soc Issues 99 at 99.

55 Chiste, supra note 31.

56 Loukacheva, supra note 52 at 89.

$57 \quad$ Ibid at 88.

58 Ibid at 90.

59 Ibid.

60 Nunavut Bureau of Statistics, Nunavut Quick Facts, online : <http://www.stats.gov.nu.ca/en/home.aspx $\geq$.

61 Nunavut Department of Executive and Intergovernmental Affairs, Nunavut FAQs, online:

$<$ https://www.gov.nu.ca/eia/information/nunavut-faqs $\geq$.

62 Ibid. 
Nunavut communities are accessible by road and, with the exception of summer access by ship, air travel is the only way to reach them.

The administration of justice in Nunavut faces two significant challenges. One relates to the conflicts between traditional and Canadian conceptions of justice. This will be addressed in Section V. The other is logistical, involving the operational difficulties of administering justice across such a vast territory. This section explores how the circuit court tries to address these logistical difficulties and presents some lingering challenges.

\section{A. The Structure and Function of Nunavut's Court of Justice}

In 1999, with the creation of the new territory of Nunavut, the Nunavut Court of Justice [NCJ] was formed as the seat of justice for these communities. Three goals were at the centre of the establishment of the NCJ: "(a) to provide substantive and procedural rights equivalent to those enjoyed elsewhere in Canada; (b) to provide court-based justice services in a fair and inclusive manner; and (c) to provide an efficient and accessible court structure capable of responding to the unique needs of Nunavut." ${ }^{\circ 3}$ With these goals in mind and recognizing the uniqueness of Nunavut's people and history, the NCJ made some adjustments to the typical Canadian structure for administering justice.

Firstly, the NCJ was to operate as a unified superior court- a distinction from elsewhere in Canada where there are divisions between superior courts and provincial/territorial courts. ${ }^{64}$ In Nunavut, the same judge would be able to hear both superior court and territorial court matters. ${ }^{65}$ Next, there would be one courthouse in Nunavut, located in Iqaluit, and the rest of the communities would be served by 'fly-in' circuit courts. In the Northern context, unification of the levels of court and the provision for 'fly-in' circuit courts went together as "[t]wo court parties flying into a community at different times and doing apparently similar but different things was a source of frustration for community residents." ${ }^{\prime 66}$ Thirdly, the NCJ bench would be greatly supported by deputy judges from across Canada who would travel to the territory and support resident judges. There are currently six judges on the NCJ bench ${ }^{67}$ who are supported by deputy judges from other provinces and territories. In 2015, deputy judges covered 44 sitting weeks in Nunavut. ${ }^{68}$ Lastly, it was envisaged that J.P.s would play a prominent role in administering justice, an element that will be discussed in Section VI. There are two full time J.P.s in the territory ${ }^{69}$ supported by lay J.P.s whose numbers have varied considerably over time. ${ }^{70}$

Concerning the lawyers operating in these courts, in 2016-2017 there were 25 staff lawyers working with legal aid across their offices in Iqaluit, Rankin Inlet, and Cambridge Bay and covering criminal, civil,

63 Scott Clark, "The Nunavut Court of Justice: An Example of Challenges and Alternatives for Communities and for the Administration of Justice" (2011) 53 Can J Corr 343 at 345.

64 Communications Branch Department of Justice Canada, Canada's Court System (Ottawa: Communications Branch Department of Justice Canada, 2005) at 7-8.

65 Ibid.

66 Clark, supra note 63 at 346.

67 The Nunavut Court of Justice, A Statistical and Comparative Review of Court Operations in Nunavut 2015 (April 2016) at 56, online: $<\mathrm{http}: / /$ www.nunavutcourts.ca/index.php/annualreports $\geq$.

68 Ibid at 58.

69 Nunavut Courts, Justice of the Peace (2019), online: <http://www.nunavutcourts.ca/index.php/jp-court $>$.

70 Clark, supra note 63 at 357. 
and family law matters. ${ }^{71}$ These lawyers were supplemented by 35 "panel lawyers"-private counsel on contract to support the Legal Services Board..$^{72}$ Over the same period, the Public Prosecution Service of Canada [PPSC] had 20 criminal prosecutors in the region, working out of offices in Iqaluit and, for Western Nunavut, an office in Yellowknife. ${ }^{73}$

Nunavut circuit courts are both time and travel intensive. For a court to sit, a court party consisting of "a judge, a clerk, a court reporter, a prosecutor, and at least one defence attorney" must travel to a community. ${ }^{74}$ Witnesses and court workers might also travel, as may interpreters, if they cannot be hired locally. ${ }^{75}$ In 2004, for instance, the circuit court travelled 177,824 kilometers, predominantly by small aircraft. ${ }^{76}$ This travel covers vast distances and is replete with logistical challenges.

For lawyers and judges in the territory, circuit courts represent a significant part of their work. In 2015, there were 65 regular circuits into Nunavut communities (excluding Iqaluit), an increase from 42 in $2002 .{ }^{77}$ Over time, it is not only the number of circuit court weeks that has grown but also the number of communities served - circuits were established in 2009 for the Whale Cove and Arviat communities. ${ }^{78}$

The periodicity of circuit court visits varies between communities. Some circuit courts will return to communities every six weeks, while others may only visit a community every two years contingent on caseload. ${ }^{79}$ Regarding the subject matter treated on circuit courts, the cases heard are predominantly —and disproportionately - criminal in nature. Violent crime rates in Nunavut are 7.1 times higher than those in Canada at large ${ }^{80}$ In 2015, 135 civil files $^{81}$ were initiated in Nunavut compared to 5527 criminal adult charges in the same year. ${ }^{82}$

Furthermore, it should be noted that Nunavut, like the rest of Canada, has an 'adversarial' procedural structure as opposed to an 'inquisitorial/investigative' procedure such as would be found in a civil law jurisdiction like France. ${ }^{83}$ In a jurisdiction in which both crime rates and poverty levels are high, this means that the circuit court system relies heavily on legal aid lawyers to function. Accordingly, the objective of providing "an efficient and accessible court structure capable of responding to the unique needs of Nunavut" is in many ways contingent on the availability of legal aid lawyers; a challenge given

Legal Services Board of Nunavut Legal Services Board of Nunavut: 2016/17 Annual Report (Iqaluit: LSB, 2017) at 1.

Ibid at 12.

Public Prosecution Service of Canada, Annual Report 2016-2017 (2017) at 26, online: $<$ https://www.ppscsppc.gc.ca/eng/pub/ar-ra/2016_2017/ar17-ra17.pdf $\_$.

74 Communications Branch Department of Justice Canada, supra note 64 at 7-8.

75 Ibid at 8

76 Nunavut Court of Justice 2004 Annual Report (2004) at 11, online: Nunavut Courts

$<$ https://www.nunavutcourts.ca/index.php/annualreports $>$.

77 The Nunavut Court of Justice, supra note 67 at 51.

78 Clark, supra note 63 at 349.

79 Communications Branch Department of Justice Canada, supra note 62 at 8.

$80 \quad$ Clark, supra note 63 at 347.

81 The Nunavut Court of Justice, supra note 67 at 46.

82 Ibid at 8 .

83 Rosalie Jukier, "The Impact of Legal Traditions on Civil Procedure: Lessons from Quebec's New Code of Civil Procedure" (2014) 93 Can Bar Rev 1; William van Caenegem, "Advantages and Disadvantages of the Adversarial System in Criminal Proceedings" (1999) 224 Law Faculty Publications online at $<$ http://epublications.bond.edu.au/law_pubs/224>. 
that they are few and overworked. ${ }^{84}$ The absence of lawyers is but one of the complaints addressed to the circuit court technology. The following sub-section details several other significant complaints against the circuit courts.

\section{B. Complaints Against the Circuit Court}

A first complaint related to the circuit courts is the disjuncture between the schedules of those providing justice and those receiving it. While judges and lawyers may feel like they are constantly travelling, the feeling for those in many communities may be that they are constantly waiting. Circuit court visits to a given community can be very infrequent. In particularly isolated communities, a circuit court may come through just once a year ${ }^{85}$ or even once every two years ${ }^{86}$ Beyond planned delays, challenging weather and mechanical obstacles can lead to further unexpected delays ${ }^{87}$ For victims, witnesses and the accused, delays often lead to stress and uncertainty. ${ }^{88}$ In instances of domestic violence, families faced with a long delay may resolve a situation themselves, only to later be put before a court, re-opening the issue long after the family has gotten over the incident themselves. ${ }^{89}$ Over time, there have been some improvements to processing times - bolstered by technical improvements like the increased use of videoconferencing in show cause hearings. Still, continued challenges with broadband access curb the overall impact of these approaches. Ultimately, many Nunavummiut remain unsatisfied with the administration of justice. ${ }^{90}$

Another complaint focuses on language and understanding. Circuit courts - as illustrated by the example of the Cape Colony ${ }^{91}$ - may depend on translation services. Though motivations for the circuit court may include accessibility and openness, these objectives are undermined where, despite being physically open, court visitors face linguistic barriers. Inuktitut and Innuinaqtun are the primary languages in most Nunavut communities and yet-despite many unilingual court participants-proceedings are predominantly in English. Courts try to overcome this barrier with interpreters and court workers, but when interpreters are present but of low proficiency, the effectiveness of the provision of justice may be called to question. ${ }^{92}$ Furthermore, linguistic translation may need to be supplemented by cultural translations where particular words do not have direct conceptual equivalents. ${ }^{93}$ According to the Nunavut Department of Justice Deputy Minister, "[a]long with this language disparity, there are cultural gaps that are probably even more significant, although not as readily evident." 94 The mere physical arrival of a circuit court in a community does not mean that it is either linguistically or conceptually accessible.

84 Clark, supra note 63 at 346, 351-353.

5 Ibid at 350.

86 Communications Branch Department of Justice Canada, supra note 64 at 8.

87 Clark, supra note 63 at 349.

88 Ibid at 350.

89 Ibid.

$90 \quad$ Ibid at 351.

91 Erasmus, supra note 1 at 287.

92 Ibid at 288.

93 Loukacheva, supra note 52 at 90.

94 Nora Sanders, “Trial Court Unification in Nunavut" in Peter H Russell, ed, Canada's Trial Courts: Two Tiers or One? (Toronto: University of Toronto Press, 2007) at 144 cited in Clark, supra note 63 at 349. 
A more deeply-rooted complaint is that many local people do not trust the circuit courts or view them as being effective. One elder noted,

[t]o me, I find them useless. I am an Inuk and they are all Qallunaat [white people]. Yes, they deal with some people that have been charged with offences and they hold court. But those that go to jail never learn from their mistakes. They are sent away to jail, but it does not deter them from repeating offences once they are back. ${ }^{95}$

Complementing this perspective, a community social worker stated "[t]his mumbo jumbo ceremony really has no meaning for people here. They fly away. They take a few people with them who magically reappear six months or a year later. It's like justice from another planet." ${ }^{96}$ Related to trust, a large number of civil cases is an indication that a society trusts its courts to fairly resolve disputes. ${ }^{97}$ In Nunavut, the ratio of civil to criminal cases is approximately $1: 40 .{ }^{98}$

There have been efforts, such as the Community Justice Program, designed to increase the agency of local peoples in managing crimes in their communities. ${ }^{99}$ Inuk-centred fora like the Community Justice Committees engage Elders, women, men, and occasionally youth in efforts to complement the formal justice system by offering culturally sensitive alternatives to established practices. ${ }^{100}$ Other efforts have included youth justice committees, northern networks of community-based action groups to confront spousal assault, and victim reconciliation programs. ${ }^{101}$ Programs like these emerged in part to strengthen the community responses that had been weakened by the imposition of southern justice practices. ${ }^{102}$ Still, for the most part, decision-making - particularly on questions of conviction-rests principally with the Court. Accordingly, the contribution of initiatives such as these tend to be secondary, focussing on sentencing and accepting referrals from the Court or RCMP - pre-charge diversions from the RCMP, or post-charge diversions from the Court. ${ }^{103}$

Do the complaints discussed above represent minor inconsistencies and misunderstandings that can be remedied by re-adjusting the circuit court technology? Or are these complaints necessary by-products of the technology itself? Recall that the circuit court was originally designed to produce outcomes like projecting power, standardizing normative compliance, and more recently, improving efficiency, impartiality, openness, and accessibility. Does a traditional Inuit conception of justice prioritize these

95 Quoted in Curt Taylor Griffiths et al Crime, Law and Justice in the Baffin Region, NWT, Canada: Final Report (Burnaby: Criminology Research Centre, Simon Fraser University, 1995) at 114 cited in Loukacheva, supra note 52 at 93.

96

97

98

99 The Nunavut Court of Justice, supra note 67.

100

101 Harald Finkler, "Community Participation in Socio-Legal Control: The Northern Context” (1992) 34:3/4 Can J Crim 503 at 508-09.

102 Ibid at 505.

103 Ibid. 
same goals? If not, what sort of technology would Inuit build to realize different goals? The following section unpacks some Inuit conceptions of justice to begin answering these questions.

\section{INUIT CONCEPTIONS OF JUSTICE}

Historically, justice in Inuit communities tended to be administered by those persons impacted by a wrong, rather than an established judicial institution. ${ }^{104}$ While angakkuq - shamans - and camp leaders often had parts to play in administering justice, it would be an overstatement to hold either as occupying a position equivalent to a J.P. or judge. Judicial procedures were not uniform but instead adaptable to the particulars of a given situation and motivated by a desire to preserve order. ${ }^{105}$

At the core of the traditional Inuit legal perspective lie three concepts: piqujait, maligait, and tirigusuusiit. Piqujait refers to "what had to be followed." Akin to customary law, piqujait relates to obligations for respecting rules of Inuit society. ${ }^{106}$ Maligait indicates what needs to be done, often interpreted as "Canadian Law." 107 Tiriquguusiit indicates what is prohibited ${ }^{108}$ - often manifesting itself as superstitions and taboos. ${ }^{109}$

Underneath these different concepts (and rough translations) rests an important element that could potentially be conceived of as procedural - the importance of relationships. Rather than general rules applied in all situations, piqujait is about complying with directions from those one respected - often elders. ${ }^{110}$ Similarly, maligait is a relational concept. The root, malik suggests "to follow a person, an animal, an idea, an object. To travel with somebody [who is not] the leader, [e.g., someone who does not own] the sled." 111 Through relationships with elders and others in their community, justice was administered.

An inherently local, relationship-based administration of justice speaks to different goals than an itinerant court. Situated in a particular place, it provides considerable room for counseling and follow-up between the accused, the 'administrator' of justice, and potentially the wronged party. Based on relationships, this administration of justice can be 'partial' and tailored to an individual's particular needs. Predominantly private, it allows for correction in the absence of public embarrassment. The following sub-sections treat these goals of counselling, partiality, and privacy in turn.

104 Willem Rasing, Too Many People: Contact, Disorder, Change in an Inuit Society, 1822-2015 (Iqaluit: Nunavut Arctic College Media, 2017) at 177.

105 Ibid at 178.

106 Jarich Oosten, Frédéric Laugrand \& Willem Rasing, Inuit Laws: Tirigusuusiit, Piqujait, and Maligait (Iqaluit: Nunavut Arctic College Media, 2017) at 1-2.

107 Ibid at 2.

108 Ibid at 1 .

109 Ibid at 3.

110 Ibid at 2 .

111 Michèle Therrien, "Inuit Concepts and Notions Regarding the Canadian Justice System" in Desmond Brice-Bennett, ed, Legal Glossary / Glossaire Juridique (Iqaluit: Nunavut Arctic College, 1997) at 255 cited in ibid at 3. 


\section{A. Counselling for Rehabilitation}

For Inuit, counselling has traditionally been part of the procedure of administering justice. A local, relationship-based administration of justice facilitates this counselling prior to punishment. Elder Joamie observes, "[t]he way it is now, it seems that people are left on their own. If we started to follow the way of our ancestors again, people would be helped and this would be very positive."112 Traditionally, each individual had a valuable part to play in society and accordingly, rehabilitation was far more important than punishment. ${ }^{113}$ A rehabilitated individual could continue to support the community while a punished individual may not. Harsh punishments were thus reserved for those individuals who rejected elders' guidance and refused to reconsider their role as a useful community member. ${ }^{114}$

Conversely, to realize the goal of rehabilitation, the effectiveness of ex post sanctions is questionable. Discussing sanctions from circuit courts in another Indigenous community one observer notes:

If the sanctions that are handed out are not endorsed by the community, they're not going to be effective... If you offend someone in your community and it is that person with whom you have to make restitution, that's going a lot further to resolving any conflict within the community than a court party flying in and out can do. ${ }^{115}$

A local, relationship-based administration of justice enables this rehabilitation in ways that the circuit court technology cannot.

\section{B. Partiality and Impartiality}

Although impartiality had typically been a central goal of the circuit court technology, in the northern context, the pursuit of impartiality may actually backfire. First, there may be the perception that flying-in from outside the community does not equate to impartiality. Second, local partiality might be a necessary element for the effective administration of justice.

For defendants in remote Indigenous communities, the simultaneous arrival of a non-Indigenous defense counsel, judge, and prosecution can lead to perceptions that allegedly 'zealous advocates' are not actually impartial. ${ }^{116}$ In northern Saskatchewan where circuit courts are also used in the administration of justice to Indigenous communities, Métis lawyer Art Durocher observes that circuit courts introduce "strangers" into the community who do not know or understand the local context. ${ }^{117}$ There is a risk that justice is not viewed as impartial and any sanctions not viewed as legitimate.

By contrast, in a relationship-based provision of justice, the impartiality of a stranger is exchanged for a sort of intentional partiality that relies on an elder knowing the story of an accused, and often also knowing the victim. A common critique of the Canadian legal system is that it is "more conducive to

112 Oosten, Laugrand \& Rasing, supra note 106 at 7.

113 Ibid at 8 .

114 Ibid.

115 Art Durocher, “A Personal Perspective on Northern Circuit Courts” in Richard Gosse, James Youngblood Henderson, \& Roger Carter (eds) Continuing Poundmaker and Riel's Quest: Presentations Made at a Conference on Aboriginal Peoples and Justice (Saskatoon: Purich Publishing, 1994) at 416 cited in Clark, supra note 63 at 363.

116 Bradford W Morse, "Native People and Legal Services in Canada" (1976) 22 McGill LJ 504 at 523.

117 Clark, supra note 63 at 363. 
regulating relations among strangers than to resolving disputes among those who are familiar and living in proximity with one another." 118 Elder Imaruittuq observes that,

[i]f there was any type of strife in the community, they used to get together and talk to the person or persons causing it. If they listened the first time, then that would be the end of the matter, but if they persisted in their misbehavior, the second round of counselling would be more severe, and unlike the first time, they did not talk about the good in the person or about how the person was loved by the community members. ${ }^{119}$

This personal way of dealing with problems was based on the respect residing in individual relationships. It allowed for one-on-one counselling with an elder in order for someone to not feel ashamed over a minor wrong; it also allowed counselling by groups of elders over more serious affairs. ${ }^{120}$ Elders could tailor the counselling to the needs of the individual, rather than treating everyone alike. Though this partiality is certainly open to critique - for instance it may not necessarily assure fairness for a victim previously marginalized in the community — such an approach exposes a gap in an exclusively "impartial" provision of justice.

\section{Privacy and Publicity}

Another key difference in the goals of Canadian justice as compared to Inuit methods relates to the openness of courts. Jeremy Bentham famously wrote that "[p]ublicity is the very soul of justice. It is the keenest spur to exertion and the surest of all guards against improbity. It keeps the judge himself while trying under trial." ${ }^{21}$ Such openness was not traditionally an inherent element of the Inuit form of administering justice. In fact, it was often quite the opposite. As Elder Joamie said, "[i]f offenders were not made to feel embarrassed, and they understood what was said to them, there would be more of a chance to improve a person's behavior." 122 Traditionally, counselling meetings with elders were held in private to avoid the spread of gossip. ${ }^{123}$ Public justice only took place in the rarest of circumstances where embarrassment was sought as punishment.

While far from a comprehensive treatment of Inuit conceptions of justice, this section has pointed to goals that are integral to Inuit justice but to which the circuit court technology does not adequately respond. It is not solely that the technology is ill-suited to realizing these goals but that the very type of technology, as per Franklin's classifications, is mismatched with the ability to realize those goals. Counselling in the manner characteristic of the Inuit administration of justice lends itself to a 'holistic' technology rather than the 'prescriptive' technology that is the circuit court. It is more readily about a craftsperson controlling the process from start to finish in order to realize a specialized result than working towards a 'compliant' outcome. A relationship-based approach to justice, replete with partiality, is more closely aligned with

118 Carol La Prairie, "Self-Government and Criminal Justice: Issues and Realities" in John H Hylton, ed, Aboriginal SelfGovernment in Canada: Current Trends and Issues (Saskatoon: Purich Publishing, 1994) at 109 cited in Chiste, supra note 31 at 166 .

119 Oosten, Laugrand \& Rasing, supra note 106 at 67

120 Ibid at 69.

121 See $A$ G (Nova Scotia) v MacIntyre, [1982] 1 SCR 175 at 7, 132 DLR (3d) 385.

122 Oosten, Laugrand \& Rasing, supra note 106 at 8.

123 Ibid at 70. 
'work-related' technologies than 'control-related' technologies-it eases the process of changing a person's behaviour rather than enabling increased control over that person. Overall, the localness of these goals fits more closely within a 'growth model' - in which justice can be nurtured and encouraged by providing a suitable environment - than a 'production model' - that would seek to control conditions to have certainty in a just product.

Recognizing that the circuit court technology itself may be a blockage to the administration of justice in the Artic, the following section explores what an alternative technology could look like to improve justice administration.

\section{TOWARDS A NEW TECHNOLOGY FOR ADMINISTERING JUSTICE IN NUNAVUT}

As demonstrated in different contexts, the circuit court has regularly relied on the technology of the 'justice of the peace' to complement its efforts in administering remote justice. As a local administrator of justice, the J.P. has allowed for greater contextual awareness, partiality, and follow-up than the circuit court in places like England, Upper Canada, and the Arctic. In Nunavut, the J.P. role has been established to complement the circuit court along with other local justice technologies such as court workers, ${ }^{124}$ justice committees, ${ }^{125}$ and elder involvement. ${ }^{126}$

As complementary technologies, however, these mechanisms do not fundamentally change the underlying circuit court technology or the challenges it engenders. Former Crown prosecutor Pierre Rousseau notes, "Nunavut's dysfunctional justice system destroys lives, ignores Inuit culture and is a major cause of inter-ethnic conflict." $127 \mathrm{He}$ continues "the use of interpreters, local justices of the peace, diversion programs, provisions for unilingual Inuktitut-speaking jurors, and elders' panels sitting with judges are just 'crumbs' thrown at aboriginal communities." 128 The system, built around the circuit court, remains a prescriptive, control-related technology set within a production model. But, could a J.P.-styled local administration of justice be an alternative to the circuit court rather than an add-on? This section turns to Greenland to explore what such an Inuit-centred technology of justice could look like. It presents an alternative vision of justice administered through a holistic, work-centred technology set in a growth model.

\section{A. Greenland's Alternative Vehicle for Administering Justice}

Greenland, like Nunavut, is a majority Inuit jurisdiction consisting of numerous remote communities and sharing a similar experience with colonial justice. The modern administration of justice, however, is markedly different. Instead of a transient fly-in structure, Greenland's courts are fundamentally local, built

124 Clark, supra note 63 at 355.

125 Chris Durrant, "None of That Paper Stuff Works: A Critique of the Legal System's Efforts to End Domestic Assault in Nunavut" (2014) 19 Appeal 50 at 62.

126 Ontario Court of Justice and Ministry of the Attorney General Joint Fly-In Court Working Group, Report on Fly-in Court Operations (August 2013) at 3, online $<$ http://www.ontariocourts.ca/ocj/files/reports/fly-in.pdf $\geq$.

127 Jim Bell, "Nunavut Courts a Scene of Ethnic Conflict: Researcher", Nunatsiaq News (3 September 2004), online $<\mathrm{http} / / / w w w . n u n a t s i a q o n l i n e . c a / s t o r i e s / a r t i c l e / n u n a v u t$ courts_a_scene_of_ethnic_conflict_researcher/.>.

128 Ibid. 
on a sedentary approach for the administration of justice that incorporates traditional knowledge and responds to contextual circumstances.

At the local level, Greenland is divided into eighteen judicial districts, each with its own district court. These district courts operate as courts of first instance and are administered by two lay assessors and one lay judge. ${ }^{129}$ While the lay judge is appointed by the High Court of Greenland, the assessors are locally elected. ${ }^{130}$ Significantly, neither the lay assessors nor the lay judge have formal legal training. Instead, the lay judge receives short appointment-related training followed by advisory support from the Greenland Court of Appeal. ${ }^{131}$

Local embeddedness rests at the centre of this model. As Loukacheva writes "the current administration of justice in Greenland is based on the principle of proximity, as the lay judges and lay assessors are recruited from among the local population and speak Greenlandic." ${ }^{132}$ Knowing the accused and being able to act partially is a central motivation for being locally embedded. Brøndsted observes, "[t]he basic principle $[\ldots]$ is that members of the local community who are familiar with the accused and his background, are regarded as better qualified to act as judges than Danish jurists." ${ }^{\prime 33}$ Moreover, it allows for the integration of Inuit substantive law into the process. As Bentzon notes, "[t]he use of Greenlandic lay judges implied that the legislators to a great extent could leave it to the discretion of the judges to take the traditional way of life and ways of thinking into consideration as needed." ${ }^{134}$ This approach resounds with an aspiration expressed by some Nunavummiut to restore power to Inuit to solve legal problems in their communities, ${ }^{135}$ reserving southern law for the most serious offences. ${ }^{136}$ This is also an approach taken for administering justice in remote Sweden, where the fly-in judge system has been replaced with locally-elected judges, effectively shifting more agency to the community in controlling the justice process. ${ }^{137}$ Could such a technology be employed in Nunavut?

\section{B. Adversarial or Investigative Procedure}

It should be noted that the NCJ was planned with the idea that resident J.P.s — preferably Inuk — would play a prominent part in the administration of justice. It was envisaged that they would rule on numerous

129 The exceptions to this are Nuuk - which has two district judges - Aasiaat and Kangaatsiaq — which share a district judge — and Paamiut and Ivituut — which also share a district judge; Loukacheva, supra note 52 at 186.

130 Ibid at 91.

131 Agnete Weis Bentzon, "Law and Legislation in Greenland during the Transition from Colonial Status to Home Rule Status (1945-1980)" (1986) 1 Law \& Anthropology 199 at 207 cited in ibid.

132 Commission on Greenland's Judicial System cited in Loukacheva, supra note 52 at 91.

133 Henning Brøndsted, "The Historical Development of the Greenlandic Judicial System" in Henrik G Jensen \& Torben Agersnap (eds) Crime, Law and Justice in Greenland (Copenhagen: New Social Science Monographs, 1996) at 121-2 cited in Loukacheva, supra note 52 at 92.

134 Agnete Weis Bentzon, "The Role of Social Science in the Administration of Sustainable Democracy" in Hanne Petersen \& Birger Poppel, eds, Dependency, Autonomy, Sustainability in the Arctic (Brookfield: Ashgate, 1999) at 130 cited in Loukacheva, supra note 52 at 92.

135 Bell, supra note 127.

136 Oosten, Laugrand \& Rasing, supra note 106 at 7.

137 Royal Commission on Aboriginal Peoples, "The Cheapest Form of Justice Possible" cited in Aboriginal Peoples and the Justice System (Ottawa: Canada Communication Group, 1993) at 458. 
summary conviction matters, giving judges more time to handle serious matters. ${ }^{138}$ Moreover, these locally-based J.P.s would reduce wait times for matters to be resolved during the circuit court, and improve accessibility (particularly linguistic). ${ }^{139}$ The plan was to have four different J.P. levels, which would rule on matters varying from administrative tasks (like oath administration) to holding trials on summary matters, to ruling on Territorial and by-law matters. ${ }^{140}$ Despite these ambitions, the NCJ has struggled to retain and train J.P.s, leading to gaps in the projected community coverage. Even still, in 2005, Nunavut had the highest number of J.P.s per capita in the country-1 per 300, a sharp contrast to Ontario with 1 J.P. per 35,435 persons. ${ }^{141}$

Some suggest that improvements to the gaps created by the circuit court can be remedied simply by 'doubling down' on the existing J.P. structure. For Clark, it is not about replacing the circuit courts, but of better combining them with local approaches to justice. ${ }^{142}$ He suggests that local J.P.s and qualified local Inuit court workers (also part of the NCJ structure) could (and should) be able to take on tasks normally handled by judges and legal aid lawyers. ${ }^{143}$ The solution lies in better stitching together the NCJ with community approaches to justice. Chiste similarly lists some advantages of having Indigenous J.P.s, noting:

$[T]$ he "flying circus" of circuit court is a highly expensive proposition in the north. But beyond cost or convenience, there were other motivations. First, there was a community desire that offenders be dealt with by those who are knowledgeable about their life circumstances and the potential consequences for community well-being of various responses to an offence. Second, there was also a desire to step out of the adversarial paradigm of the court system, whose confrontational nature is one of the most frequently cited failings of the mainstream justice system with respect to Aboriginal peoples. ${ }^{144}$

But, if the problems of the current system could be solved simply by slight adjustments, why have they persisted, especially considering the strong interest and commitment of Nunavummiut? What changes would be required to ensure that J.P.s do not regress to 'playing second-fiddle' to the circuit court?

A possible explanation and potential solution rests in the nature of Greenland's procedural system. Greenland is a civil law jurisdiction ${ }^{145}$ and, as such, judges play an 'investigative' role. Whereas a common law judge's role is more passive, facilitating the 'adversarial' process by allowing parties to put forward their best evidence, a civil law judge is more active, looking for "objective truth." The judge's role has significant implications on how the system works.

138 Clark, supra note 63 at 356.

139 Nora Sanders, "Trial Court Unification in Nunavut" in Peter H Russell, ed, Canada's Trial Courts: Two Tiers or One?

(Toronto: University of Toronto Press, 2007) at 148 cited in ibid at 357.

140 Clark, supra note 63 at 357.

141 Chiste, supra note 31 at 164.

142 Clark, supra note 63 at 363.

143 Ibid at 351.

144 Chiste, supra note 31 at 166-167.

145 Loukacheva, supra note 52 at 87. 
In the southern context, Sherr observes, an investigative approach can help remedy problems related to self-represented litigants by allowing judges to ask more questions and become more engaged in evidentiary processes. ${ }^{146}$ Moreover, Sherr contends, while an adversarial system requires high amounts of legal aid funding for legal representation, an investigative system does not rely as heavily on lawyers. Accordingly, an investigative system is able to direct more funds to the courts, judicial system, and the time judges spend on problems. ${ }^{147}$ All these factors align with goals such as counseling (the system is more inclined to work with the accused to find the truth), partiality (where, absent an adversarial system, there is less concern of validating one party over the other), and privacy (by enabling more control for in camera sessions).

Additionally, in a northern context, a locally embedded judge with greater discretion could potentially be a better broker of the needs of local justice — overcoming the feeling that many Nunavut J.P.s have when faced with interpersonal offences of being pulled between the obligation of acting without bias and the need to be attuned to community and cultural practices. ${ }^{148}$ Such a role could be more appealing to potential J.P.s and more effective in realizing Inuit goals. Ownership of the judicial institution in this sense could be a major dimension of legal empowerment in the Arctic, allowing Inuit to exercise greater control over their lives. ${ }^{149}$

Exchanging or 'transplanting' one procedural system for another is not straightforward. ${ }^{150}$ Legal transplantation may involve complex processes of selection, resistance, reform, and integration. ${ }^{151}$ In the Arctic, however, it seems the Inuit legal culture has already - and for some time - been rejecting the transplant of the common law adversarial procedural system. Given the closer alignment of an investigative procedural system with Inuit goals, this transplant may be more readily selected and integrated into northern justice.

\section{CONCLUSION}

Like a wheel-barrow being pulled across a field of craggy ice, the Nunavut circuit courts are a technology ill-suited to the northern context in which they are being used. While circuit courts serve a functional role in advancing justice across the landscape, the journey is more arduous and less effective than it could be with another technology. If, as Goldstein notes, "societies [...] see their basic values

146 Avrom Sherr, "Shrinking Legal Aid, Unrepresented Litigants and Judicial Independence" in Shimon Shetreet \& Christopher Forsyth, eds, The Culture of Judicial Independence: Conceptual Foundations and Practical Challenges (Boston: Martinus Niihoff Publishers, 2011).

147 Ibid at 404.

148 Chiste, supra note 31 at 167.

149 Dan Banik, "Legal Empowerment as a Conceptual and Operational Tool in Poverty Eradication" (2009) 1 Hague J Rule of Law 117 at 128.

150 Sherr, supra note 146 at 410.

151 Kun Fan, "Glocalization of Arbitration: Transnational Standards Struggling with Local Norms Through the Lens of Arbitration Transplantation in China" (2013) 18 Harv Negot L Rev 175. 
reflected more in the procedural systems than in their substantive law,"152 the values reflected in the circuit court are those of southern Canada, objectives often at odds with Inuit norms.

Alfred observes that in Nunavut, though "the Inuit people are now the titular heads of government [...] the apparatus of government is staffed and controlled mainly by white southerners." 153 Durrant suggests that a similar situation exists in the justice system. ${ }^{154}$ Though the NCJ is part of the fabric of the Inuitmajority territory of Nunavut, the concept of justice it represents does not contain either the substantive or procedural law elements of Inuit justice. In contexts such as these, it is clear who "owns" the justice system and who is "subject" to it. ${ }^{155}$

As this paper has attempted to demonstrate, legal empowerment is a question that stretches beyond substantial law to judicial institutions, procedural technologies, and who controls those processes. Rather than presenting a solution to the challenges of administering justice across a vast geography, circuit courts have become part of the problem. However, for the residents of the North, there is a potential alternative technology to the circuit court in the technology of resident Indigenous judges operating in an investigative procedural structure. While, like a qamatik travelling across the ice, the journey will still be hard, this technology may be far better suited to succeeding in the context and realizing the goals of those who live there.

152 Gerald Goldstein, "The Odd Couple: Common Law Procedure and Civilian Substantive Law” (2003) 78 Tul L Rev 291 at 293 cited in Jukier, supra note 83 at 213.

153 Taiaiake Alfred, Peace, Power, Righteousness: An Indigenous Manifesto, 2nd ed (Toronto: Oxford University Press, 2009) at 27.

154 Durrant, supra note 125 at 50.

155 Freire, supra note 10 at 196. 